NOTE

\title{
Prevalence of microscopic tubercular lesions in freshwater ornamental fish exhibiting clinical signs of non-specific chronic disease
}

\author{
Serafín Gómez* \\ Histología y Anatomía Patológica, Facultad de Veterinaria, Universidad de Murcia, 30100 Murcia, Spain
}

\begin{abstract}
A histopathological study of tubercular lesions in ornamental freshwater fish showing clinical signs of chronic sporadic disease was carried out using conventional and acid-fast staining. A total of 200 individuals of 38 species were examined for granulomatous lesions related to the occurrence of acid-fast bacteria. Tubercular lesions were found in 24 species. Systematic histopathological examination was used to assess the incidence of fish tuberculosis in aquaria.
\end{abstract}

KEY WORDS: Fish tuberculosis $\cdot$ Mycobacteriosis $\cdot$ Histopathology

Resale or republication not permitted without written consent of the publisher

\section{INTRODUCTION}

Mycobacteriosis or fish tuberculosis is a systemic infectious disease, usually characterized by a chronic course, caused by several species of Mycobacterium. The most frequently isolated mycobacterial species considered to be pathogenic for fish are $M$. marinum, M. fortuitum and M. chelonae (Belas et al. 1995, Decostere et al. 2004). Tuberculosis in fish was first described in a carp from a nodule localised in the abdominal wall (Bataillon et al. 1897). Following that report, the disease has been found in sea fish and freshwater fish species, both in the wild and in commercial establishments and aquaria (Sakanari et al. 1983, Daoust et al. 1989, Bragg et al. 1990, Conroy \& Conroy 1999, Dos Santos et al. 2002, Gauthier et al. 2003, Prearo et al. 2004).

The treatment of fish tuberculosis is questionable. Studies carried out to demonstrate the efficacy of tuberculosis treatments in fish have shown controversial results with varying degrees of drug sensitivity exhibited by the mycobacteria (Santacana et al. 1982, Hedrick et al. 1987, Lawhavinit et al. 1988, Colorni 1992, Boos et al. 1995, Colorni et al. 1998, Conroy \& Conroy 1999, Yanong et al. 2003).

Mycobacteria implicated in the development of chronic inflammatory lesions in fish are capable of causing chronic infections in humans. Mycobacterium marinum infections are emerging infections related to the aquarium fish hobby (Aubry et al. 2002).

The aim of the present study was to investigate the occurrence of tubercular lesions in ornamental freshwater fishes with sporadic, non-specific chronic clinical signs of disease using a systematic histopathological analysis.

\section{MATERIALS AND METHODS}

The present histopathological study was conducted with 200 individuals of 38 freshwater aquarium fish taxa (Table 1), collected from pet shops and private owners. The selected fish showed signs of chronic disease (persistent skin and ocular lesions, poor body condition and abdominal swelling). Samples for the present histopathological study were fixed in Bouin's fluid or $10 \%$ neutral buffered formalin solution and embedded in paraffin using standard methods (Luna 1968). Sections were stained with haematoxylin-eosin (H\&E). In accordance with the size of the fish, histopathological examination was performed on complete or partial tissue sections. When granulomatous lesions were found, further sections were stained with a modified Ziehl-Neelsen (ZN) method for acid-fast bacteria (Ellis 
Table 1. Histopathological examination of ornamental freshwater fish. Positive reactions based on microscopic granulomatous inflammation in tissue sections and presence of acid-fast bacteria

\begin{tabular}{|c|c|c|}
\hline & $\begin{array}{c}\text { Fish } \\
\text { positive }\end{array}$ & $\begin{array}{c}\text { Fish } \\
\text { examined }\end{array}$ \\
\hline \multicolumn{3}{|l|}{ Family Cyprinidae } \\
\hline Fathead minnow Pimephales promelas & 1 & 5 \\
\hline White cloud mountain minnow Tanichthys albonubes & 2 & 13 \\
\hline \multicolumn{3}{|l|}{ Family Characidae } \\
\hline Blood fins tetra Aphyocharax anisitsi & 1 & 1 \\
\hline Buenos Aires tetra Hyphessobrycon anisitsi & 1 & 3 \\
\hline Red eye tetra Moenkhausia sanctaefilomenae & 1 & 1 \\
\hline Piranha Serrasalmus sp. & 1 & 1 \\
\hline \multicolumn{3}{|l|}{ Family Adrianichthyidae } \\
\hline Medaka Oryzias latipes & 8 & 32 \\
\hline \multicolumn{3}{|l|}{ Family Poeciliidae } \\
\hline Guppy Poecilia reticulata & 17 & 34 \\
\hline Swordtail Xiphophorus hellerii & 4 & 8 \\
\hline Variegated platy Xiphophorus variatus & 19 & 22 \\
\hline \multicolumn{3}{|l|}{ Family Cyprinodontidae } \\
\hline American flagfish Jordanella floridae & 6 & 6 \\
\hline \multicolumn{3}{|l|}{ Family Cichlidae } \\
\hline Chanchito Cichlasoma facetum & 1 & 1 \\
\hline Convict cichlid Archocentrus nigrofasciatus & 2 & 2 \\
\hline Purple cichlid Pelvicachromis pulcher & 1 & 2 \\
\hline Freshwater angelfish Pterophyllum scalare & 1 & 1 \\
\hline African cichlid Pseudotropheus sp. & 1 & 1 \\
\hline Discus fish Symphysodon sp. & 3 & 7 \\
\hline \multicolumn{3}{|l|}{ Family Osphronemidae } \\
\hline Siamese fighting fish Betta splendens & 1 & 2 \\
\hline Striped gourami Colisa fasciata & 1 & 1 \\
\hline Dwarf gourami Colisa lalia & 2 & 4 \\
\hline Black paradise fish Macropodus hongkongensis & 1 & 2 \\
\hline Paradise fish Macropodus opercularis & 2 & 14 \\
\hline Pearl gourami Trichogaster leeri & 1 & 1 \\
\hline Three spot gourami Trichogaster trichopterus & 3 & 4 \\
\hline
\end{tabular}

pseudobranch. The non-necrotizing nodular granulomas consisted of aggregates of epithelioid macrophages. Secondary changes such as confluence, peripheral fibrosis and degree of necrosis were variable. Multinucleated giant cells and dystrophic calcification in granulomas were occasionally observed. The presence of acid-fast bacilli associated with tubercular lesions was confirmed by the ZN stain. In positive cases, varying numbers of beaded, non-filamentous, non-branching, intensely stained acid-fast bacilli were found either extracellularly or within macrophages (Fig. 4). The extent of tubercular infection based on the abundance and size of granulomas in internal organs was variable. In advanced cases, the entire parenchyma was virtually replaced by coalescing granulomas. The basic histological features of tubercular infection are similar in all fish species studied. The morphological variability of the granulomas could be related to the chronological development of the disease.

\section{DISCUSSION}

The results of the present histopathological study have shown that ca. $40 \%$ of the specimens examined had \& Zabrowarny 1993). In all cases, a positive control was included. Sections were evaluated for granulomatous inflammation and associated acid-fast bacilli.

\section{RESULTS}

Granulomatous inflammation associated with acidfast bacteria was confirmed histologically in 81 of 200 $(40.5 \%)$ fish studied (Table 1). Histopathological examination of infected individuals revealed the presence of diffuse (Fig. 1) or nodular granulomatous inflammation in various severities of infection (Figs. 2 \& 3) in skin (usually granulomatous dermatitis, ulcerative form), eye (granulomatous endophthalmitis, panophthalmitis and choroiditis), gills, muscle (usually granulomatous myositis, ulcerative form) and internal organs. Lesions were generally found in the digestive tract, peritoneum, pancreas, liver, spleen, heart, kidney, gonads, central nervous system, swimbladder and tubercular lesions in various degrees of development. The morphological patterns of the granulomatous

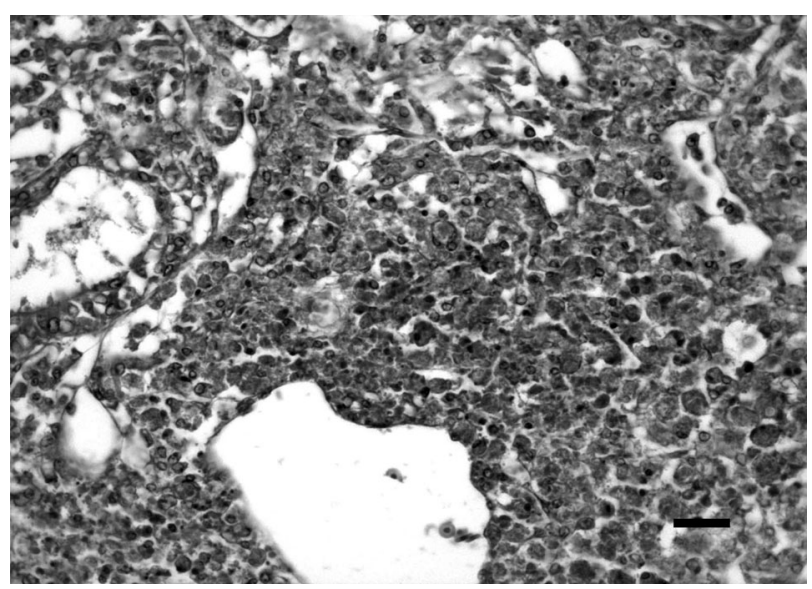

Fig. 1. Macropodus opercularis. Diffuse granulomatous infiltrate in kidney. Haematoxylin-eosin stain. Scale bar $=20 \mu \mathrm{m}$ 


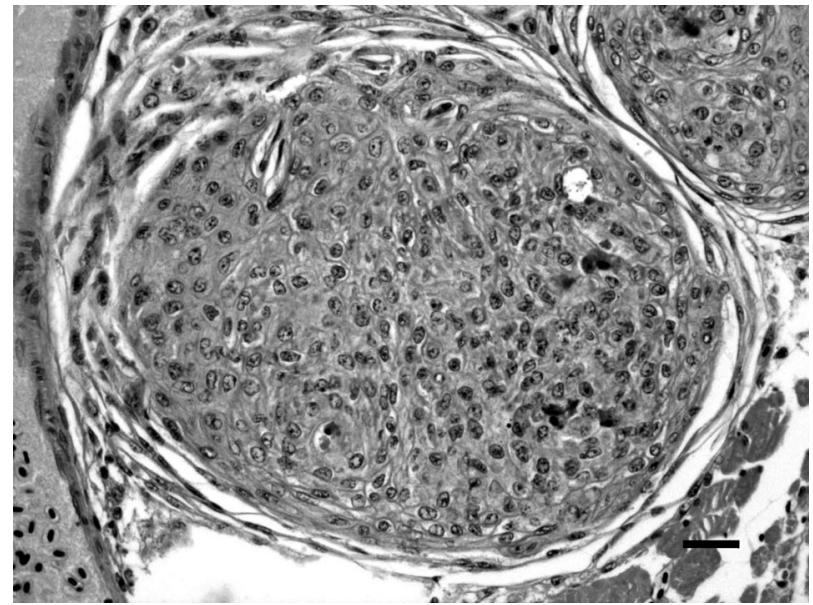

Fig. 2. Aphyocharax anisitsi. Non-necrotizing granuloma. Haematoxylin-eosin stain. Scale bar $=20 \mu \mathrm{m}$

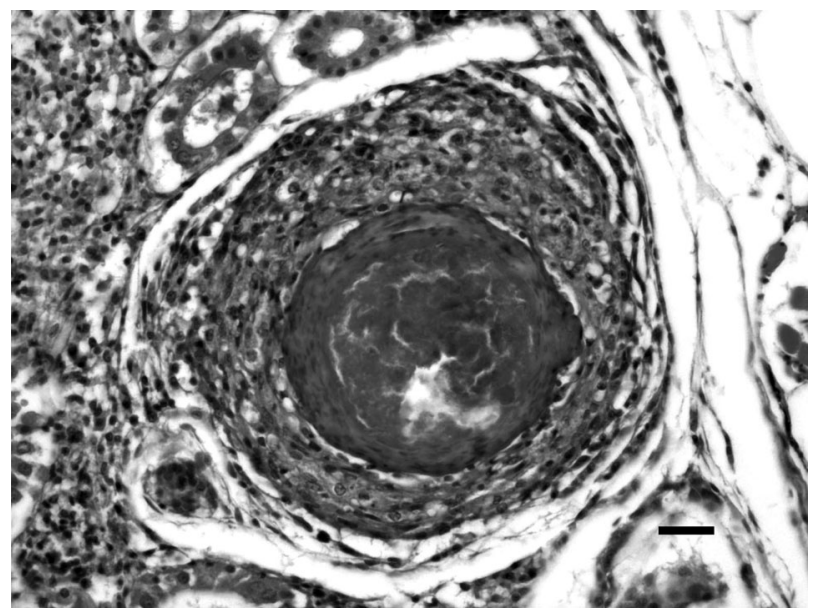

Fig. 3. Poecilia reticulata. Necrotizing granuloma in kidney. Haematoxylin-eosin stain. Scale bar $=20 \mu \mathrm{m}$

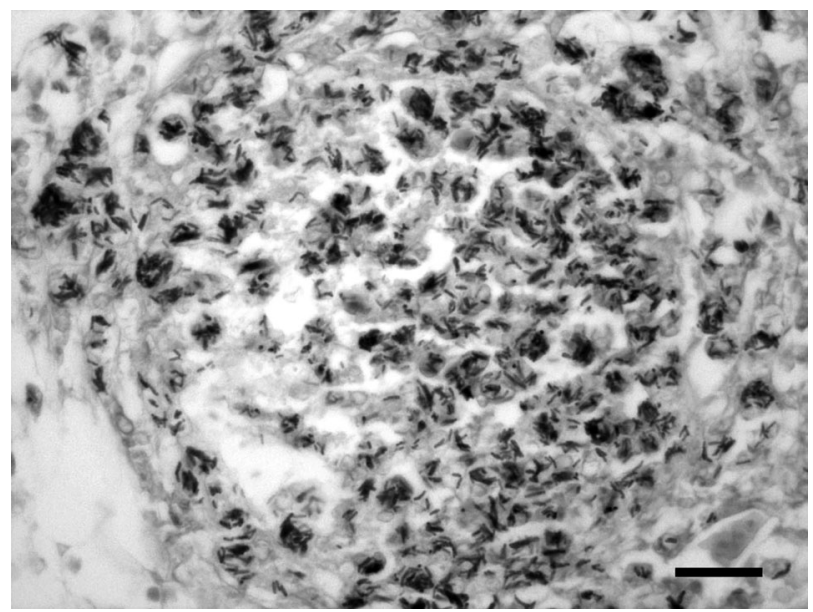

Fig. 4. Macropodus opercularis. Granuloma containing numerous acid-fast bacteria. Ziehl-Neelsen stain. Scale bar $=20 \mu \mathrm{m}$ lesions are related to stages of infection as described in experimentally infected fish (Talaat et al. 1998, Gauthier et al. 2003) or after a spontaneous infection (Majeed et al. 1981, Colorni 1992). The different types of mycobacterial granulomas found in fish have been classified according to the presence or absence of central necrosis. In the spontaneous disease, the presence of both conditions, non-necrotizing (hard) and necrotizing (soft) granulomas, in the same individual would be related to the progress of the lesions and the tissue in which they are found. Non-necrotizing (epithelioid) granulomas are formed at an earlier stage of disease. Confluent granulomas with or without necrosis can be present in cases with severe involvement, replacing the normal tissue. The pathology of goldfish experimentally infected with Mycobacterium marinum was dependent on the inoculum dose and the time postinfection of animal sacrifice. The chronic disease is characterized by systemic granuloma formation (Talaat et al. 1998). Although described as a chronic process, the disease may evolve without gross lesions such as gray to white nodules in multiple organs or microscopic or histopathologic evidence of granulomatous disease that is generally associated with mycobacteriosis in fish (Talaat et al. 1998, Yanong et al. 2003). Under experimental conditions $M$. marinum causes a chronic, progressive disease of the zebrafish Danio rerio in a dose-dependent fashion. The extent and progression of $M$. marinum granulomatous disease is both time- and dose-dependent (Swaim et al. 2006). M. marinum establishes an acute or chronic infection in the medaka Oryzias latipes in a dose-dependent manner (Broussard \& Ennis 2007).

In the present study granulomatous lesions were found in the skin, eye and internal organs, perhaps denoting the infection routes. Likewise, the finding of granulomas in the oral cavity of some individuals could be related to infections derived from the eroded mucosa. Mycobacterial infection in zebrafish is acquired primarily through the intestinal tract (Harriff et al. 2007). In ovoviviparous fishes, there is also the possibility of transovarian transmission of mycobacteria to embryos undergoing development (Conroy \& Conroy 1999). The frequent occurrence of ovarian lesions that we found in ovoviviparous fishes explains the vertical transmission of the disease. In the oviparous Siamese fighting fish Betta splendens, the transmission of mycobacteria via transovarian lesions has been confirmed (Chinabut et al. 1994).

Fish tuberculosis is a disease which is considered to be linked to deficiencies in hygiene, overcrowding or malnutrition. However, outbreaks are known to have occurred in rearing premises where water quality values remained within optimal ranges (Teska et al. 1997). Most specimens examined in the present study 
originated from aquaria in which ambient conditions were adequate. Once mycobacteriosis is endemic within an established colony, it is difficult to eradicate (Astrofsky et al. 2000). Atypical mycobacteria causing disease in fish are normal inhabitants of a wide variety of environmental aquatic reservoirs. It can be assumed that the incidence of mycobacterial infections in aquarium fish is primarily associated with mycobacterial contamination of the aquarium environment (Beran et al. 2006).

The present histopathological study shows that gross pathology, where nodules are assumed to be indicative of tubercular disease in fish, can be useful only when the state of disease is advanced and when the size of the fish allows a suitable necropsy. The isolation of mycobacteria does not necessarily mean that the disease is present. Cultures are not always obtained even when large numbers of bacilli are seen in lesions. Mycobacteria can be isolated from the skin, musculature, gills and internal organs of clinically healthy ornamental fish (Beran et al. 2006). In addition, attempts at isolating the aetiological agent often fail (Austin \& Austin 1999). It is a process which, owing to its insidious pattern of development and the varying forms which it adopts, is only rarely diagnosed by aquarists. The clinical signs that suggest fish tuberculosis, however, are non-specific. Anorexia, emaciation, cachexia, lethargy, skin ulcers, protruding of the scales, unilateral or bilateral exophtalmos, keratitis, panophthalmitis, abdominal swelling, or spinal deformation were found in the present study. Likewise, symptoms of fish tuberculosis may consist of lesions that can only be detected microscopically. These characteristic lesions which contain large numbers of acidfast bacilli are considered pathognomonic (Chinabut et al. 1990). For this reason, a systemic histopathological examination of suspected cases of fish tuberculosis is essential for a differential diagnostic and must become a routine analysis to asses the incidence of this disease in aquaria individuals.

Acknowledgements. The author expresses his appreciation to Prof. J. Serrano for helpful suggestions and J. Sánchez for technical assistance.

\section{LITERATURE CITED}

Astrofsky KM, Schrenzel MD, Bullis RA, Smolowitz RM, Fox JG (2000) Diagnosis and management of atypical Mycobacterium spp. infections in established laboratory zebrafish (Brachydanio rerio) facilities. Comp Med 50:666-672

Aubry A, Chosidow O, Caumes E, Robert J, Cambau E (2002) Sixty-three cases of Mycobacterium marinum infection: clinical features, treatment, and antibiotic susceptibility of causative isolates. Arch Intern Med 162:1746-1752

Austin B, Austin DA (1999). Bacterial fish pathogens: disease of farmed and wild fish, 3rd edn. Springer-Praxis Publishing, Chichester

Bataillon E, Dubard J, Terre L (1897) Un nouveau type de tuberculose. C R Séances Soc Biol Fr 49:446-449

Belas R, Faloon P, Hannaford A (1995) Potential applications of molecular biology to the study of fish mycobacteriosis. Annu Rev Fish Dis 5:133-173

Beran V, Matlova L, Dvorska L, Svastova P, Pavlik I (2006) Distribution of mycobacteria in clinically healthy ornamental fish and their aquarium environment. J Fish Dis 29:383-393

Boos S, Schmidt H, Ritter G, Manz D (1995) Untersuchungen zur oralen Wirksamkeit von Rifampicin gegen die Mykobakteriose der Zierfische. Berl Munch Tierarztl Wochenschr 108:253-255

> Bragg RR, Huchzermeyer HF, Hanisch MA (1990) Mycobacterium fortuitum isolated from three species of fish in South Africa. Onderstepoort J Vet Res 57:101-102

Broussard GW, Ennis DN (2007) Mycobacterium marinum produces long-term chronic infections in medaka: a new animal model for studying human tuberculosis. Comp Biochem Physiol 45:4554

> Chinabut S, Limsuwan C, Chanratchakool P (1990) Mycobacteriosis in the snakehead, Channa striatus (Fowler). J Fish Dis 13:531-535

Chinabut S, Kanayat IY, Pungkachonboon T (1994) Study of transovarian transmission of mycobacteria in Betta splendens Regan. In: Chou ML, Munro AD, Lam TJ, Chen TW and others (eds) The 3rd Asian Fish Forum, Manila, p 339-341

Colorni A (1992) A systemic mycobacteriosis in the European sea bass Dicentrarchus labrax cultured in Eilat (Red Sea). Isr J Aquac Bamidgeh 44: 75-81

Colorni A, Avtalion R, Knibb W, Berger E, Colorni B, Timan B (1998) Histopathology of sea bass (Dicentrarchus labrax) infected with Mycobacterium marinum and treated with streptomycin and garlic (Allium sativum) extract. Aquaculture 160:1-17

> Conroy G, Conroy DA (1999) Acid-fast infection and its control in guppies (Lebistes reticulatus) reared on an ornamental fish farm in Venezuela. Vet Rec 144:177-178

Daoust PY, Larson BE, Johnson GR (1989) Mycobacteriosis in yellow perch (Perca flavescens) from two lakes in Alberta. J Wildl Dis 25:31-37

> Decostere A, Hermans K, Haesebrouck F (2004) Piscine mycobacteriosis: a literature review covering the agent and the disease it causes in fish and humans. Vet Microbiol 99:159-166

> Dos Santos NM, Do Vale A, Sousa MJ, Silva MT (2002) Mycobacterial infection in farmed turbot Scophthalmus maximus. Dis Aquat Org 52:87-91

> Ellis RC, Zabrowarny LA (1993) Safer staining method for acid fast bacilli. J Clin Pathol 46:559-560

> Gauthier DT, Rhodes MW, Vogelbein WK, Kator H, Ottinger CA (2003) Experimental mycobacteriosis in striped bass Morone saxatilis. Dis Aquat Org 54:105-117

$>$ Harriff MJ, Bermudez LE, Kent ML (2007) Experimental exposure of zebrafish, Danio rerio (Hamilton), to Mycobacterium marinum and Mycobacterium peregrinum reveals the gastrointestinal tract as the primary route of infection: a potential model for environmental mycobacterial infection. J Fish Dis 30:587-600

Hedrick R, Mcdowell T, Groff J (1987) Mycobacteriosis in cultured striped bass from California. J Zoo Wildl Med 23:391-395

Lawhavinit O, Hatai K, Kubota S, Toda K, Suzuki N (1988) Treatment of Mycobacterium infection in pejerrey, Odon- 
thestes bonariensis C \& V. Bull Nippon Vet Zootech Coll $37: 35-38$

Luna LG (ed) (1968) Manual of histologic staining methods of the Armed Forces Institute of Pathology, 3rd edn. McGraw-Hill, New York

Majeed SK, Gopinath C, Jolly DW (1981) Pathology of spontaneous tuberculosis and pseudotuberculosis in fish. J Fish Dis 4:507-512

Prearo M, Zanoni RG, Campo Dall'Orto B, Pavoletti E, Florio D, Penati V, Ghittino C (2004) Mycobacterioses: emerging pathologies in aquarium fish. Vet Res Commun 28:315-317

Sakanari JA, Reilly CA, Moser M (1983) Tubercular lesions in Pacific Coast population of striped bass. Trans Am Fish Soc 112:565-566

Santacana JA, Conroy DA, Mujica ME, Marín C, De López N (1982) Acid-fast bacterial infection and its control in three-

Editorial responsibility: John Austin, Oldendorf/Luhe, Germany spot gouramies, Trichogaster trichopterus Pallas. J Fish Dis 5:545-547

Swaim LE, Connolly LE, Volkman HE, Humbert O, Born DE, Ramakrishnan L (2006) Mycobacterium marinum infection of adult zebrafish causes caseating granulomatous tuberculosis and is moderated by adaptive immunity. Infect Immun 74:6108-6117

Talaat AM, Reimschuessel R, Wasserman SS, Trucksis M (1998) Goldfish, Carassius auratus, a novel animal model for the study of Mycobacterium marinum pathogenesis. Infect Immun 66:2938-2942

Teska JD, Twerdok IE, Beaman J, Curry M, Finch RA (1997) Isolation of Mycobacterium abscessus from Japanese Medaka. J Aquat Anim Health 9:234-238

Yanong RP, Curtis EW, Terrell SP, Case G (2003) Atypical presentation of mycobacteriosis in a collection of frogfish (Antennarius striatus). J Zoo Wildl Med 34:400-407

Submitted: October 18, 2007; Accepted: May 19, 2008 Proofs received from author(s): June 27, 2008 